\title{
Finansal Tabloların Sunumunda XBRL Kullanımı: ABD Örneği ve Türkiye'de Uygulanabilirliği
}

\author{
XBRL on Provide of Financial Statements: Aplication on USA and \\ Aplicable on Turkey
}

\section{Dr. Meriç Yıldırım - Yrd. Doç. Dr. Jale Sağlar}

\section{Öz}

Türkçeye Genişletilebilir İşletme Raporlama Dili olarak çevrilen XBRL (eXtensible Business Reporting Language) Amerika ve Avrupanın belirli ülkelerinde kullanılan bir işaretleme dilidir. Temel fonksiyonu muhasebe süreci içerisinde kullanilan finansal bilgilerin belirli muhasebe ilkelerine veya standartlarma uygun bir şekilde raporlanmasın sağlamaktır. Çalıșma XBRL'in en yaygin olarak kullanıldığı ülkelerden biri olan ABD'deki kullanımın belirlemek ve yakın gelecekte kullanmaya başlanacak olan Türkiye'de kullanılabilirliğini tespit etmek amacıyla hazırlanmıştır. Çalışma sonucunda ABD'nde XBRL'in kullanımının uygulayıcılar açısından yararlı kabul edildiği, ancak belirli bir maliyete katlanılması gerektiği ve katılımcılarm finansal bilginin dönüştürülmesinde kullanılan etiketlemelerin(taksonomilerin) kullanımının işletmelere birakilmasinı istedikleri bunun da finansal manüplasyon riskini arttırdığı anlaşılmaktadır. Çalışmada Türkiye'de IMKB' ${ }^{\prime}$ de işlem gören firma yetkililerinin büyük çoğunluğunun XBRL ile ilgili bilgi sahibi olmadığı, bilgi sahibi olan kısmin ise XBRL kullanımın finansal raporlama üzerine olumlu etkileri olacağına inandiğı ancak bununla ilgili çok yüksek maliyete katlanmak istemedikleri tespit edilmiştir.

Anahtar Kelimeler: Finansal Tablolar, XBRL, Türkiye'de XBRL Kullanımı

\begin{abstract}
Extensible Business Reporting Language (XBRL), which is translated into Turkish as "Genişletilebilir İsletme Raporlama Dili" is a markup language employed in USA and various European countries. It is employed to assure that the financial information used in accounting process is reported in accordance with the accounting principles or standards. This study aims to investigate the application of XBRL in USA, where it is widely employed, as well as its applicability in Turkey, where it will be used in the near future. We provide evidence suggesting that XBRL's application is considered very useful by those who use it, in USA. However, its application introduces extra costs. In addition, users of XBRL argue that the application of the taxonomy that is used in the transformation of financial information, should be decided by companies arbitrarily, which could potentially lead to an increase in the risk of financial manipulation. Based on survey evidence, majority of the participants of the survey do not have information about XBRL. Who have information about XBRL, suggest that they believe that XBRL could have a positive effect on financial reporting. However, their companies would not bear the extra costs associated with its application.
\end{abstract}

Keywords: Financial Statements, XBRL, Aplicable of XBRL on Turkey

Dr. Meriç Yıldırım, Crown Bevcan Türkiye-Mali İşler Md., meric.yildirim@eur.crowncork.com

Yrd. Doç. Dr. Jale Sağlar, Çukurova Üniversitesi İIBF, jsaglar@cu.edu.tr

1 06.12.2012 tarih 6362 sayılı (yeni) Sermaye Piyasası Kanununun 138. Maddesine istinaden Türkiye’de faaliyet gösteren Borsaların tüzel kişilikleri Borsa İstanbul A.Ş.(BİST)'nin kuruluşunun tescili ile sona ermiş ve İMKB’nin tüm hakları yeni şirkete devredilmiştir. 


\section{Giriş}

6102 sayılı yeni Türk Ticaret Kanununun 69.maddesinde şirketlerin yıl sonu finansal tablolarının Türkiye Muhasebe Standartlarına(TMS) uygun olarak hazırlanacağı hüküm altına alınmıştır. Bu hüküm muhasebe kayitlarını 3568 sayılı SMMM ve YMM Kanununa bağlı olarak çıkarılan 1 sıra no.lu Muhasebe Sistemi Uygulama Genel Tebliği doğrultusunda tutmakla yükümlü bulunan şirketlerin bu sorumluluğunu ortadan kaldırmamaktadır. Bu durum şirketlerin 2013 yılından itibaren finansal tablolarını hem MSUGT’ne göre hem de TMS'na göre hazırlanacağını hatta TMS'ye uygun bir şekilde çevrileceğini göstermektedir. Türkiye'de muhasebe ve denetim standartlarının oluşturulmasından ve uygulanmasından sorumlu kurum olan Kamu Gözetimi Muhasebe ve Denetim Standartları Kurumu XBRL(eXtensible Business Reporting Language - Genişletilebilir İşletme Raporlama Dili) Türkiye Temsilciliğinin kurulduğunu 25 Kasim 2013 tarihinde basin duyurusu ile duyurmuştur. Bu XBRL'in yakın gelecekte Türkiye'de de uygulanabileceğinin bir göstergesi niteliğindedir.

XBRL, XML tabanlı olan, bir işletmenin finansal raporlarının sunulmasında kolaylıklar sağlayan ve yine uluslararası geçerliliği olan bir işaretleme dilidir (Waldt, 2004). Diğer bir ifade ile XBRL, finansal bilginin hazırlanması, raporlanması, yayınlanması ve denetlenmesini kolaylaştıran, standart hale getirilmiş elektronik bir dildir (Murthya and Groomer, 2004, s. 139-163; Berkeley, 2001). Her bir kalem bireysel olarak etiketlendiği için, bir finansal tablo XBRL ile yasal düzenleyiciler, yatırımcılar, analistler ve finansörler gibi tabloyu hazırlayan kuruluşun başlıca ilgilileri tarafından talep edilen farklı versiyonlara otomatik olarak dönüştürülebilmektedir (Malhotra, Garritt, 2004, s. 61). Örneğin, XBRL dokümanları internette yayımlandıktan sonra ilgili finansal bilgi kullanıcıları otomatik olarak buradan hangi grupta olursa olsun her bir kişisel bilgiye görsel olarak erişebilir. Bu açıdan XBRL sadece bir tanımlama dili değil, bilişim toplumunun entegrasyonu ve standardizasyonu için bir teknolojik standartlar ailesi konumundadır (Best, 2009).

Bununla beraber XBRL, üzerinde anlaşılmış veri etiketleme sistemine bağlı olarak veri yayınlanmasina imkân tanımaktadır. Bu sayede de satışlar ve kar gibi verilerin değişik açılardan (işletme, sektör vb...) karşılaştırılmasına da imkân sağlamaktadır (Teixeira, 2005, 14). XBRL basit bir ifadeyle; finansal verileri etiketleme sistemi olarakta tanımlanabilir. Burada etiketler; nakit, borç gibi finansal olaylar hakkındaki bilgileri içermektedir. Etiketlenen bu finansal olaylar dijital ortamda bilgiye dönüştürülmektedir. XBRL ortaminda Web`de gezinen finansal bilgi kullanıcıları, otomatik olarak, XBRL tabanlı raporlanan finansal tablolardan günlük satışların veya alacakların, hâsılattaki büyüme ile karşılaştırmalı analizinin yapılması gibi özellikli bir bilgiye erişebilecektir (Anł derson, 2002, s. 97). Örneğin işletmeler, XBRL tabanlı finansal tabloları internette yayımladıklarında bilgi kullanıcılarının bu raporlara online olarak ulaşması mümkün olacaktır. Sürdürülmekte olan çalışmaların, XBRL`nin bütün faaliyet sınıflandırmalarına ilişkin versiyonlarının geliştirilmesinde ön ayak olacağı beklenilmektedir (Anderson, 2002, s. 98).

\section{Finanasal Tabloların Hazırlanmasında XBRL Kullanımı}

XBRL'in uygulama aşamaları yüzeysel yaklaşım, raporlama seviyesinde uygulama yaklaşımı ve ERP yazılımlarında kayıt bazında detaylı uygulama yaklaşımı olmak üzere 3 farklı ana grupta sinıflandıs rulabilir (Garbellotto, 2009, s. 11).

Yüzeysel Yaklaşım: Yüzeysel yaklaşım finansal tabloların alışılmış yöntemlerle üretildikten sonra harici olarak XBRL formatına dönüştürülerek raporlanmasinı temsil etmektedir. Uygulamaya benzer olarak dokümanların ".pdf”, “.xls” veya “.xlsx" formatına dönüştürülmesi verilebilir (Ohata, 2008, s. 17).

Raporlama Seviyesinde Uygulama Yaklaşımı: XBRL'in raporlama seviyesinde uygulanması gerekli XBRL dönüşümlerini kullanılan yazılımlar ile yapabilme imkânı tanıması sebebiyle aynı zamanda şirket içi raporlamalarda da kullanılabileceği anlamına gelir. Bu durum ise şirket içi fayda elde edebilmek anlamina gelmektedir (Garbellotto, 2009, s. 12-13).

ERP yazılımlarında kayıt bazında detaylı uygulama yaklaşımı: XBRL'in en gelişmiş ve derinlemesine kullanım izni veren uygulama seviyesidir. Ancak bu yöntemle XBRL defterleri düzenlenebilir ve kullanılan finansal sistemlerdeki neredeyse tüm bilgi XBRL formatında raporlanabilir (Garbellotto, 2009, s. 14). Tabii ki kullanılan bu yöntem en gelişmiş yöntem olmakla beraber en maliyetli yöntem olma özelliğini de taşımaktadır. Garbellotto, uzun vadede XBRL'i kullanmayı hedefleyen ve XBRL’i sadece yasal bir zo- 
runluluk olarak değil aynı zamanda şirket içi raporlamasında da iş yükünü azaltacak ve çeşitli esneklikleri sağlayabilecek bir altyapı olarak gören işletmelerin bu yöntemde bir uygulama yöntemi içine gireceğini söylemektedir(Garbellotto, 2009, s. 15). XBRL etiketlemelerle detaylı veriler işletme içinde tutulabilmekte ve daha sonra özetlenerek finansal raporlamada kullanılabilmektedir. XBRL iç raporlamalar konusundaki esnekliğini aynı zamanda holdingler bazında farklı kurum ve kuruluşlar bazında da ortaya koymakta ve güçlü alt yapısını raporlama sürecinde gösterebilmektedir. XBRL hem konsolidasyon süreçlerindeki kontrolleri artırmakta hem de konsolidasyon ve finansal raporlama süreçlerini ciddi oranda azaltmaktadır.

XBRL ile ilgili olarak ifade edilen bilgilerin yanında konunun daha da netleştirilmesi amaciyla ve XBRL'ye sahip olduğundan daha fazla bir anlam yüklememek amacıyla, XBRL’nin ne olmadığı üzerinde de durmak gerekmektedir (Berkeley, 2001; XBRL, 2009). Buna göre;

- XBRL bir muhasebe standardı dizisi değildir. XBRL sadece muhasebe standartlarının ve içeriğinin internet ortaminda raporlanması ve sunulmasını sağlamaktadır.

- XBRL uluslararası muhasebe hesap adı değildir. Sadece bu hesapların verilerinin sunulmasinı sağlamaktadır.

- XBRL Genel Kabul Görmüş Muhasebe İlkelerinin/Muhasebe Standartlarının çeviricisi konumunda da değildir. Sadece bu ilke ve standartların aynı ilke ve standartlar doğrultusunda sunulmasını sağlamaktadır.

- XBRL ücretli bir teknoloji değildir. Ücretsiz lisansı bulunan ve kamuya açık bir dildir. Çeşitli yazılım uygulamalarında kullanılabilmesi için XML tabanlı oluşturulmuştur.

- XBRL muhasebe uygulama programı da değildir. Sadece muhasebenin kendi siniflandırmalarına bağlı kalarak bunların raporlanmasını elektronik ortamda sağlamaktadır.

\section{XBRL'in ABD'de Kullanımı ve Türkiye'de Kullanılabilirliği}

$\mathrm{Bu}$ araştırmada bilgi teknolojilerinden internet tabanlı merkezi raporlama sistemlerinden XBRL'in Türkiye'de kullanılabilirliğini ortaya koymak amaçlanmaktadır. Bu açıdan çalışma iki kısma ayrılmıştır. Birinci kısım XBRL kullanan firma yöneticilerinin
XBRL öncesi ve sonrasındaki gelişimini kıyaslamaları ile ilgili temsil çalışma temelindedir. Bu nedenle XBRL'in yoğun kullandığ kullanan firmalara yönelik bir anket çalışması yapılmıştır. Uygulama çalışmasının Amerika Birleşik Devletlerinde yapılmasının en önemli sebebi, ABD'nin XBRL uygulamasını halka açık şirketler tarafından hayata geçirmiş olması ve XBRL ile finansal raporlama üzerinde en çok aşama kaydeden lider ülke konumunda olmasıdır (XBRL, 2009). İkinci kısımda ise Türkiye'de uygulanabilirliği ve şirketlerin bu uygulamaya yaklaşımını belirlemek amaçlanmaktadır. $\mathrm{Bu}$ amaçla Türkiye IMKB’ye kayıtlı firmalara yönelik ayrı bir bir anket çalışması yapılmıştır.

\section{Çalışmanın Kapsamı}

ABD'de XBRL raporlamasının sadece Amerika Menkul Kıymetler Komisyonuna kayıtlı olarak çalışan sermaye şirketleri tarafından yapilıyor olması nedeniyle Aralık 2010 tarihi itibarı ile Amerika Menkul Kiymetler Komisyonuna kayıtlı ve XBRL'e göre finansal raporlama yapan 332 firma bulunmaktadir. $\mathrm{Bu}$ kütleden örneklem yoluyla 140 firma seçilerek bu firmaların yetkililerinden anket yoluyla bilgi edinilmiştir. Firmaların yetkililerine ABD Menkul Kıymetler Komisyonunun veritabanından, XBRL kullanıcılarının bilgi paylaşımı amacıyla oluşturmuş olduğu ortak 6 ayrı profesyonel çalışma grubundan ve dosyalamayı fiilen yapan yetkililerin oluşturmuş olduğu ortak bir XBRL platformundan kişilerle direkt bağlantı kurularak ulaşılmıştır. Gönderilen anket formlarından 118 adedi cevaplanarak geri gönderilmiş ve değerlendirme dışı bırakılan anket olmamıştır.

Türkiye'de XBRL'in kullanılabilirliğini tespit edebilmek amacıyla Türkiye'deki halka açı firmaların yetkililerinin görüşlerini alabilmek için Aralık 2010 tarihi itibarı ile SPK' ya kayıtlı olup IMKB'de işlem gören 339 halka açık firmadan aynı holding çatısı altında bulunan toplam 43 iştirak şirketi ve toplam 74 gayrimenkul yatırım ortaklığ aracı kurum hizmeti veren firma finansal raporlama sürecini, ana holdingleri bünyesinde yaptıklarından dolayı mükerrer cevaplamaların elimine edilmesi amacıyla kapsam dışı bırakılmıştır. Elde edilen 222 firma ana kütle olarak belirlenmiş ve bu firmalardan rastgele örneklem yoluyla 100 firma seçilerek anket çalışması yapılmıştır. Araştırma kapsamına alınan IMKB’ye bağlı firma yetkililerinin iletişim bilgilerine Kamuyu Aydınlatma Platformu aracilı̆̆ıyla ulaşılmış ve örneklem kapsamında belirlenen 100 firmanın 
yetkililerine anket soru kâğıdı gönderilmiştir. Gönderilen anket formlarından 69 adedi cevaplanarak geri gönderilmiştir. Anketlerde ciddi oranda bir veri eksikliği olmaması sebebiyle geri dönüşü yapılan 69 anketin tamamı değerlendirme kapsamına alınmış ve değerlendirme dışında bırakılan anket olmamıştır. Çalışma iki kısımda yapıldığından değerlendirmede ayrı ayrı yapılmış ve sonuçlar karşıllaştırılmıştır.

Çalışma kapsamında cevaplayıcılara bireysel olarak ulaşabilmek için ABD Menkul Kıymetler Komisyonunun halka açık olan veritabanında komisyonun önerdiği incelemeler gerçekleştirilmiş ve bazı iletişim adreslerine erişilmiştir. Bunların dışında farklı portal ve platformlarda XBRL dosyalamasını yapan farklı kişilerle bağlantı kurularak uygulama çalışmalarına katılımları rica edilmiştir. Bağlantı kurulan bazı danışmanlar ve bu alanda gerek etiketlerin oluşturulmasinda gerekse de komisyonda aktif görevlerde yıllar içerisinde ciddi çalışmalar sürdürerek XBRL projesine emek veren diğer kişilerle kurulan bağlantılar aracılığıyla farklı firmalara ve bölüm yöneticilerine ulaşılabilmiş ve ana kütle içerisine alınan firma veritabanı geliştirilebilmiştir.

\section{Araştırmanın Kısıtları}

1. ABD'de yapılan uygulama da araştırma çalışması yatırımcıların adres ve iletişim bilgilerini temin etme olanağı olmaması nedeniyle SEC'e bağlı şirketlerin yönetim kademesinde XBRL raporlamasından sorumlu yöneticiler bazında gerçekleștirilmiştir. $\mathrm{Bu}$ nedenlerle yatırımcılar gibi son bilgi kullanıcıları bazında bir değerlendirme yapılamamıştır.

2. Bütün anket çalışmalarında karşılaşılan yapısal sorunların bu çalışmada da geçerli olduğu varsayılmaktadır. Bu çerçevede, ankette sadece net ve gerekli sorular sorulmuştur. Ayrıca, ABD uygulamasında, katılımcılarının bir kısmının XBRL formatında finansal raporlama yapması yanında XBRL'in ylllar içerisinde gelişiminde etiketlerin ilgili muhasebe standartları ile oluşturulması aşamasında ve ABD Menkul Kıymetler Komisyonu içerisinde farklı görevlerle oluşturulan alt komisyonlarda görevler alarak bu konuda ciddi bilgi ve tecrübeye ulaşmış olmaları anket sonuçlarının güvenilirliğini artırmaktadır.

3. Anket çalışmalarından sağlıklı cevaplar alabilmek için uzaktan iletişim yerine bire bir ve yüz yüze ilişkiler kurmak ve cevapları bu şekilde almak en uygun yaklaşım olsa da bu, uygulamanın okyanus aşırı gerçekleştirilmesi ve zaman kısıtı nedeni ile gerçekleştirilememiştir. Sadece ön test çalışmaları bire bir ve telekonferans şeklinde yapılabilmiştir.

4. Çalışma 2010 yılında yapıldığından 2010 yılı sonrası düşünceleri yansıtmamaktadır.

\section{ABD'de XBRL Kullanımının Değerlendirilmesi}

Katılımcıların bazıları anket sorularına ek olarak yıllar içerisinde kazandıkları tecrübeleri e-mail yolu ile bildirmişler ve konu ile ilgili olarak düşüncelerini paylaşmışlardır. Değerlendirmelerde sadece verilen cevaplar değil karşıllkklı iletişsim ile elde edilen bilgiler de esas alınmıştır. Ankete verilen cevapların oransal dağılımı Tablo 1'de sunulmaktadır.

1. 2000'li yillarda yaşanan finansal skandallar sonrası finansal bilgi kullanıcılarının hem şirket yönetimlerine hem de bu şirketlerin denetimlerini gerçekleştiren bağımsız denetim kuruluşlarına güvenleri tamamen sarsılmıştır. \%74,6'lık olumlu katılım ABD Menkul Kiymetler Komisyonunun 2002 yılında fiilen başlatmış olduğu ve bu tarihten bugüne dek üzerinde ciddi emekler verilerek bugüne getirilen XBRL projesinin en temel amaçlarından birisi olan finansal şeffaflığın ortamının oluşturulmasında önemli bir yol alındığı görülmektedir.

2. Her ne kadar bu soruya katılma oranı yüksek görünse de katılmama oranı da dikkate alınmasi gereken bir orandir. Bunun sebepleri arasında XBRL projesinin bugünkü uygulama aşamaları itibarı ile halen istenilen noktada olmaması, şirket yönetimleri tarafından manuel müdahaleye açık olması ve finansal manipülasyonun önlenmesinde istenilen uygulama aşamalarının henüz halen hayata geçirilememiş olması düşünülebilir.

3. $\% 88,1^{\prime}$ lik oran ankete cevap veren katılımciların XBRL kullanımının finansal şeffaflı̆̆ı sağlamasına rağmen finansal güvenilirliği sağlamayacağına inandıklarını göstermektedir. Finansal şeffaflık ve finansal manipülasyon ihtimali yargılarına verilen cevaplardan katılımcıların XBRL’in finansal şeffaflığı sağlamasına rağmen 
Tablo 1. ABD'de Yapılan Anket Sarularına Verilen Cevapların Oransal Dağılımları ${ }^{2}$

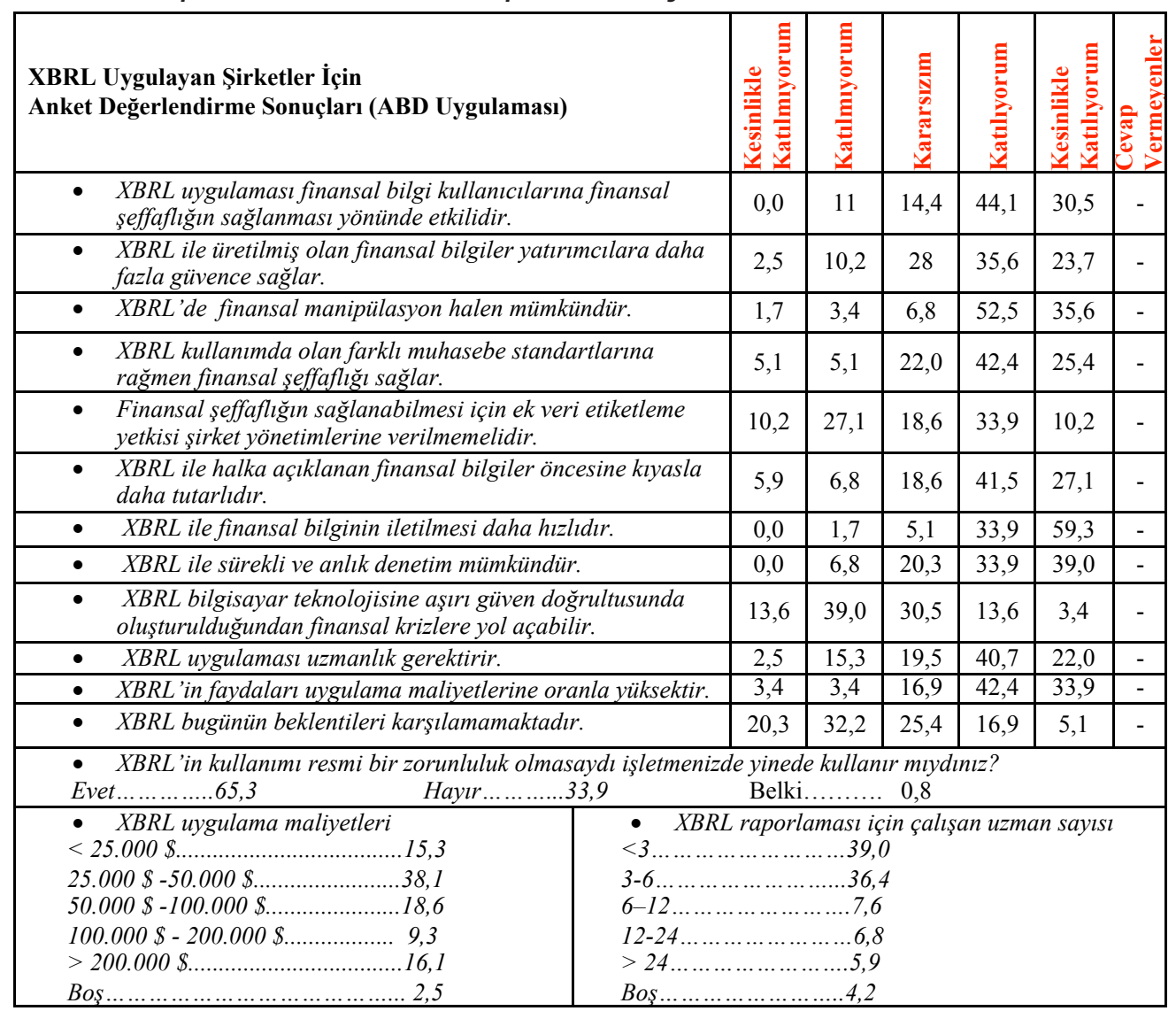

finansal manipülasyon ihtimalinin halen yüksek olduğunu düşündükleri anlaşılmaktadır. Çapraz incelemede XBRL'in finansal şeffaflığı sağlayacağ yönünde görüş bildiren katılımcıların 78'inin aynı zamanda finansal manipülasyon yapılabilme olanağının varlığı yönünde de görüş bildirdiği anlaşılmaktadır. Bu da tüm değerlendirmeler içerisinde \% 66,1 oranında bir katılım oranı olduğunu göstermektedir. XBRL ile finansal şeffaflı̆̆ın sağlanabileceğine inanan katılımcılarin finansal manipülasyon ihtimalinin halen var olduğunu düşünmelerinin şirket yönetimlerinin XBRL formatında yayınlanan finansal verilere müdahale şansının halen mümkün olmasından kaynaklı olduğu düşünülmektedir. Katılımcıların cevaplarından ABD Menkul Kıymetler Komisyonunun XBRL uygulamasının hayata geçi- rilmesi aşamasında belirli bir seviyede uygulama zorunluluğu getirmemesi sonucunda XBRL'in bugünkü uygulama seviyeleri ile değerlendirmeler yaptıkları düşünülmektedir. XBRL'in tüm uygulama aşamalarının ileri ki dönemler itibariyle tamamlanması halinde şirket yönetimlerinin yetkinliklerinin azaltılması ile beraber şirket yöneticilerinin finansal makyajlama adı altında yaptıkları finansal manipülasyon riskinin elimine edilmesi mümkün olabilecektir.

4. Katılım oranına bakıldığında bu soruya cevap verenlerin XBRL kullanımının farklı muhasebe uygulamalarında etkin sonuçlar vereceğine inandıkları anlaşılmaktadır. ABD Menkul Kıymetler Komisyonunun ortak bir finansal raporlama aracı olarak XBRL üzerinde çalışmaya başladığı

2 Tablo içerisinde verilen sonuçların tamamı \% değeri ile sunulmaktadır. 
2002 yıllarının başında ısrarcı bir şekilde sadece ortak bir raporlama aracı değil aynı zamanda IFRS gibi ortak bir muhasebe standardına gerekliliği vurgulaması ve sonrasında ilerleyen yıllarda U.S. GAAP'e uyumlu etiketlerin de yaratılması amacıyla başlatmış olduğu projeyle gösterdiği esneklik anket sonuçlarında XBRL kullanıcılarının cevaplarında da benzer şekilde görünmektedir.

5. Aynı şekilde katılımcıların $\% 37,3$ 'ü şirket yönetimlerinin ek veri etiketleme yetkisine sahip olmasının finansal şeffaflık açısından bir sıkıntı yaratacağına katılmamaktadırlar. Bunun nedeninin ise şirket yönetimlerinin finansal tablolar üzerinde yapmayı istemiş olduğu makyajlama hakkını ellerinde tutma isteği olarak anlaşılmaktadır. Ek veri etiketleme yetkisine sahip olmak şirket yönetimlerinin tamamen bu hedefin dışına çıkması anlamına gelmektedir. Şirket yönetimlerinin ek veri etiketleme yetkisine sahip olabilmesi, şirket yönetimlerinin finansal tablo kalemleri üzerinde oynama yapabilme yetisi tanımaktır ki bu XBRL'in eleştirilen yönlerinden biridir. Komisyonun oluşturulan etiketlerin her sektör ve firma için yeterli olmayacağ 1 görüşünde olması dolayısıyla ek veri etiketleme yetkisi firmalara verilmiş olup bunun etiketleme işlelerinin gelişim sürecinin tamamlanmasından sonra ortadan kaldırılması planlanmaktadır.

6. Bu soruya verilen cevaplar finansal manipülasyon ihtimali yargısına verilen cevaplarla tutarlı değildir. Bunun sebebi şu an itibariyle XBRL'in finansal manipülasyonu önlemediği ancak tutarlllı̆̆ arttırdığıdır. Bu görüş finansal şeffaflığın etkinliği yargısına verilen cevaplarla tutarlıdır. XBRL ABD Menkul Kıymetler Komisyonu başta olmak üzere tüm yetkili otoritelerin ortak bir karara bağlayıp sonuçlandırdıkları ortak bir etiketlerin kullanması itibariyle farklı dönemler itibarı ile benzer yapıda raporlamalar yapmaya olanak sağlamaktadır ve bu durum XBRL katılımcilarının bildirdikleri görüşlerden de kolayca anlaşılmaktadır. Katılımcıların cevapları aslında uzun yıllar içerisinde çalışmalar sonucu oluşturulmuş olan ve halen gelişim sürecinde bulunan etiketlere olan güvenin farklı bir göstergesi niteliğindedir.

7. XBRL kullanıcılarının \%93,2'si XBRL raporlaması ile finansal bilgiye daha hızlı ulaşma imkânı bulunduğunu bildirmişlerdir. Bu durum,
XBRL’in şeffaflı̆̆ sağlayan unsurlardan zamanlılık kavramını sağladığını göstermektedir. Zamanında açıklanan finansal bilgiler doğrultusunda finansal şeffaflık ortamı muhafaza edilebilecek ve bilgi kullanıcıları zamanında bilgilendirilebilecektir.

8. XBRL kullanıcılarının \%72,9'u XBRL ile sürekli ve anlık denetim yapma olanağının mümkün olduğu konusunda görüş bildirmişlerdir. Katılımcıların \%20,3 oranında önemli bir kısmı bu konuda kararsız kaldıklarını belirtmiştir. XBRL'in hayata geçirilme düşüncelerinden bir tanesi de finansal bilgi kullanıcılarına sağlanan finansal tablolardaki verilerin denetim olanağının artırılması ve mümkün oldukça örnekleme yoluyla yapılan denetimden sürekli denetime geçiş olanağının oluşturulabilmesidir. Bunun finansal güvenilirliği artıracağı aşikârdır. Ankete katılanlar XBRL kullanımının finansal manipülasyonu önlemediğini belirtse de zamanla aralıksız denetim ile finansal manipülasyonun önlenmesinde daha olumlu ilerlemeler kaydedilebilecektir. Anketi cevaplayan XBRL kullanıcılarının görüşleri doğrultusunda bugün bu hedefin ciddi oranda gerçekleştiğini görmek mümkündür.

9. XBRL kullanıcılarının \%52,5'i XBRL'in bilgisayar teknolojilerine aşırı güven doğrultusunda oluşturulmuş olmasının bir finansal krize yol açmayacağ 1 konusunda görüş bildirmişlerdir. Katılımcıların önemli bir boyutunu oluşturan \% 30,5'lik kısım ise bu konuda kararsız oldukları yönde görüş bildirmişlerdir. Bu yargıya olumlu yönde görüş bildiren \%16,9'luk katılımcı diliminin verdiği cevaplardan tamamen elektronik ortamda gerçekleştirilen finansal raporlama işlevlerinin anlık erişime ve kötü niyetli kullanıma açık olmasının bazı güvenlik sıkıntıları yaşayabileceklerini düşündükleri ve güvenlik sıkıntıları dolayısı ile de yeni bir finansal krize sebebiyet verebilecekleri düşüncesine sahip oldukları anlaşılmaktadır.

10. XBRL uygulama aşamaları itibariyle farklı seviyelerde kullanılabilen esnek bir yapıya sahiptir. Dolayısı ile uygulamadaki temel farklılığında firma değerlendirmelerine yansıdığı net bir şekilde verilen cevaplardan görülmektedir. Çalışmanın yapıldığı yılda, ABD Menkul Kıymetler Komisyonu halka açık firmaların XBRL rapor- 
lamalarını şirket bünyelerine adapte etmeleri ve projenin bir an önce hayata geçirilmesi amaciyla uygulamanın ne seviyede yapılacağı konusunda her hangi bir yaptırım zorunluluğunda bulunmamıştır. Uygulamanın istenilen detay seviyede gerçekleştirilmesi için zorunluluk olarak gündeme geldiğinde raporlama süreçlerinde uzman kişilerden yardımına ihtiyaç duyulabilecektir. Detay seviyede uygulamayı hayata geçiren firmalar geçiş aşamasında daha çok bu alanda uzmanlaşmış olan danışman firmalarla çalışmayı seçme yoluna gittikleri bilinmektedir.

11. XBRL kullanıcılarının \%76,3'ü XBRL'in faydalarının ve getirilerinin uygulamanın firmalara getireceği ek maliyetlerle kıyaslandığında yinede uygulamaya değer olacağını bildirmişlerdir. $\mathrm{Bu}$ da katılımcılar açısından finansal verilerin kaydedilmesi ve raporlanması sürecinde XBRL kullanımının yararlı olduğuna inandıklarını göstermektedir. Katılımciların manuel raporlamalarının sayısının azaltılabilecek olmasının, kontrol ve analiz süreçlerinin etkinliğinin artırılabilecek olmasının uzun vadede katlanılan maliyetler için uygulamayı hayata geçirmeyi değer kılacağı yönde düşündükleri anlaşılmaktadır.

12. XBRL kullanıcılarının \%52,5'i XBRL'in bilgi kullanıcılarının bugünkü beklentilerini karşıladığını belirtmişlerdir. Bununla beraber XBRL kullanıcılarının \%22'sinin XBRL'in bilgi kullanıcılarının beklentileri halen tam olarak karşılayamadığı yönünde düşündükleri anlaşılmaktadır. Katılımc1ların \%25,4'ü bu konuda kararsız kaldıkları yönde görüş bildirmişlerdir. \%25,4'lük oranda katılımcının XBRL'in hayata geçirilmesinde temel amaçlarından finansal manipülasyon yapabilme olanağının azaltılıp finansal şeffaflık ortamını kuvvetlendirme ihtiyacı içinde olmasının henüz uygulamadaki eksiklikler dolayısı ile sağlanamamış olmasını düşündükleri anlaşılmaktadır. $\mathrm{Bu}$ durum ise finansal manipülasyon ihtimali yargısına verilen cevaplar ile uyum içerisindedir. XBRL'in gelişim aşamasını tamamlamasından sonra ancak temel hedefleri üzerinde daha etkin bir noktaya geleceği düşünülmektedir.

13. XBRL kullanıcılarının $\% 65,3$ 'ü XBRL'in kullanımının ABD Menkul Kıymetler Komisyonu tarafindan bir zorunluluk olarak getirilmese bile kullanmayı tercih edecekleri yönünde görüş belirtmişlerdir. \%65,3’lük gönüllü katılımcı grubunun verdiği cevaplar aynı zamanda XBRL'in finansal bilginin hızlı iletimindeki etkinliği ve XBRL'in getirilerinin uygulama maliyetlerine k1yaslanması yargılarına verilen cevaplarla paralellik göstermektedir. XBRL’in gönüllü olarak tercih edilmesinin en önemli nedenleri arasında daha hızlı ve tutarlı raporlamaları yapabilme olanağı ve manuel iş yükünü azaltma imkânı verilebilir.

14. XBRL kullanıcılarının katlandığı uygulama maliyetleri farklı aralıklarda yoğunlaşmaktadır. Ankete katılan firmaların sermaye yapıları 5 milyar \$’ı üzerinde ve birbirine yakın büyüklüktedir. Bu dağılım her firmanın XBRL için farklı tutarda yatırım yaptığını göstermektedir. ABD Menkul Kiymetler Komisyonu XBRL ile hazırlanan finansal raporların ilgili dönemler itibariyle XBRL etiketlere uygun olarak hazırlanmasını zorunlu tutmuş ancak, uygulamanın hangi seviyede gerçekleştirilmesi gerektiği konusunda bir zorunluluk getirmemiştir. Dolayısı ile firmaların bazılarının uygulama maliyetlerini düşürmek amacıyla ciddi yatırımlar yapmadığı bazılarının ise geleceğe yönelik çalışmalar için detay bazda bir uygulama süreci geçirdiği yapılan inceleme kapsamında tespit edilmiştir.

15. XBRL kullanıcılarının XBRL uygulamasında çalışan uzman sayısının dağılımı da farklılıklar göstermekle beraber ortalama 1-6 kişi arasında yopun bir dağılım olduğu tespit edilmiştir. Varilen bilgilerden çok fazla sayıda personel gerektirmediği anlaşılmaktadır.

\section{XBRL'in Türkiye'de Kullanılabilirliği}

Bu kapsamda IMKB'ye bağlı firmalara anket formu aracilığıyla ulaşılmış ve veriler toplanmıştır. Anket uygulama çalışmasının ikinci aşamasını oluşturan Türkiye uygulamasında SPK firmaları bazında yapılan anket çalışmasından elde edilen yüzdesel dağılım Tablo 2'de sunulmuştur. Buna göre;

1. IMKB'ye bağlı firma yetkililerinin $\% 53,6$ 'sı gibi büyük çoğunluğu (37 firma yöneticisi) web tabanlı merkezi raporlama dilleri hakkında bilgi sahibi olmadıklarını belirtmektedir. Verilen cevaplar dikkate alındığında, XBRL kullanımının Türkiye açısından uygulanabilmesi için öncelikle farkındalık seviyesinin arttırılması gerektiği anlaşılmaktadır. XBRL altyapısına uygun olarak 
yapılabilecek yeni bir potansiyel finansal raporlama sürecinde işletmelerin önceden bilgi sahibi olmalarının geçiş sürecini daha verimli kılacağı düşünülmektedir.

2. IMKB’ye bağlı firma yetkililerinin $\% 92,8$ 'i sermaye piyasalarında sağlıklı bir büyümenin ancak finansal şeffaflığın sağlanabilmesi ile mümkün olacağını belirtmiştir. Bu da çok yüksek bir oranla Türkiye'de IMKB'ye bağlı firma yetkililerin, ABD'de SEC'e bağlı olarak sermaye piyasalarında işlem gören halka açık firma yetkililerinin degerlendirmelerine paralel olarak sermaye piyasalarında sağlıklı bir büyümenin ancak finansal şeffaflık ortamı ile sağlanabileceği yönünde bir görüş birliğine sahip olduklarını göstermektedir. Her iki ülkede de halka açık firma yetkililerinin sağlıklı bir ekonomik büyüme için aynı görüşe sahip olduklarını yüksek katılım oranları ile görmek ekonomik büyümede finansal şeffaflı̆ıın önemini bir kez daha ortaya koymaktadır.

3. IMKB'ye bağlı firma yetkililerinin verdikleri cevaplardan anlaşılacağı üzere, ankete katılanların büyük çoğunluğu $(\% 92,8)$ finansal şeffaflı̆̆ın finansal krizleri önlediğini düşündüğünü belirtmiştir. Finansal krizlerin önlenebilmesi de ancak finansal güvenilirlikle mümkündür. Finansal güvenilirliğin elde edilmesinde finansal şeffaflı̆̆ın önemi değerlendirmelerden anlaşılmaktadır.

4. Bundan sonraki anket soruları XBRL'in kullanımı ile ilgili detaylı bilgiler içermekte olup bu sorular ile ilgili olan yorumlar bu konuda bilgi sahibi olan 32 katılımcının vermiş olduğu cevaplar dikkate alınarak hazırlanmıştır. Bu firma yetkililerinin \%78,1'i web tabanlı merkezi bir raporlama dilinin hayata geçirilmesi ile şirket yönetimlerinin finansal verilere müdahale olanağının ortadan kaldırılmasının finansal şeffaflı̆̆ın elde edilmesinde etkili olacağı görüşüne katıldıkları görülmektedir. Bu yüksek katılım oranı merkezi bir raporlama aracı ile şirket yönetimlerinin kendi inisiyatiflerinde finansal verilere müdahale etme şansının ortadan kaldırılmasının yapılacak raporların doğruluğu ve güvenilirliğini ne derecede etkileyeceğinin diğer bir göstergesidir.

5. Firma yetkililerinin $\% 75$ 'i web tabanlı merkezi bir raporlama dili ile hazırlanan finansal tabloların yatırımcılara yatırım kararlarında daha fazla güvence vereceği konusunda olumlu görüş bildirmişlerdir. Verilen cevaplardan merkezi bir raporlama dili ile standart bir formatta detaylı raporlamaların yapilabilir olmasının IMKB'ye bağlı firma yetkilileri tarafından finansal şeffaflığı sağlamada daha etkili olacağını düşündükleri anlaşılmaktadır.

6. Firma yetkililerinin $\% 81,3$ 'ü web tabanlı merkezi bir raporlama dili ile sürekli ve anlık denetim imkânının elde edilebilmesinin finansal şeffaflığın sağlanmasında etkili olacağ 1 konusunda olumlu görüş bildirmişlerdir. Verilen cevaplardan aralıksız ve anlık denetim imkânının XBRL altyapısı ile sağlanmasının yayınlanan finansal bilgilere olan güveni artıracağı anlaşılmaktadır. Finansal bilgilere olan güvenin artmasının beraberinde finansal şeffaflık ortamını olumlu yönde etkileyeceği yapılan değerlendirmelerden görülmektedir.

7. Firma yetkililerinin $\% 84,4$ 'ü web tabanlı merkezi bir raporlama dili ile periyodik finansal raporlamalar yerine anlık finansal raporlamaların yapılabilir olmasının finansal şeffaflık ortamını kuvvetlendireceği konusunda olumlu görüş bildirmişlerdir.

8. Firma yetkililerinin $\% 71,9^{\prime} \mathrm{u}$ XBRL'in ilerleyen ylllarda Türkiye'de potansiyel kullanımının mümkün olacağı yönde görüş bildirirken, \%6,3’ü bu görüşe olumsuz yanıt vermiş̧ir. Katılımcıların \%18,8'i bu konuda kararsız oldukları yönde bir görüş bildirirken, \%3,1'lik bir kısım ise konu hakkında herhangi bir görüş bildirmemişlerdir. IMKB'ye bağlı firmaların bugünkü uygulamaları itibarı ile farklı altyapı ve platformlarda benzer uygulamalar yapıyor olmaları ileriki yıllarda Türkiye’de Kamu Gözetim Kurumunun XBRL Türkite Temsilciliğinin kurulduğunu bildirmesi ile çok yakın bir gelecekte XBRL kullanımına geçileceği aşikardır.

9. IMKB’ye bağlı firma yetkililerinin \%56,3'ü Türkiyedeki teknolojik altyapının XBRL'in ilerleyen yıllarda kullanılabilmesi için yeterli olacağı konusunda olumlu görüş bildirirken, $\% 34,4$ 'ü bu konuda kararsız oldukları yönde bir görüş bildirmişlerdir. Katılımcıların yüksek oranda kararsız kalmalarının sebebinin konu hakkında düşük bilgi seviyesine sahip olmaları olabilir. 
Tablo 2. Türkiye'de Yapılan Anket Sarularına Verilen Cevapların Oransal Dağılımları

\begin{tabular}{|c|c|c|c|c|c|c|}
\hline $\begin{array}{l}\text { XBRL Uygulamaları Üzerine İMKB Kayıtlı Firmalar Anket } \\
\text { Değerlendirme Sonuçları (Türkiye Uygulaması) }\end{array}$ & 要 & 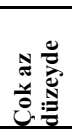 & تِّ: & : & 背总 & $\frac{N}{\grave{n}}$ \\
\hline \multirow[t]{2}{*}{$\begin{array}{l}\text { 1. Web tabanlı merkezi raporlama dilleri(XML, XBRL gibi) hakkında } \\
\text { bilgi düzeyiniz }\end{array}$} & 53,6 & 31,9 & 10,1 & 1,4 & 2,9 & -- \\
\hline & 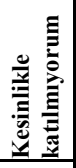 & 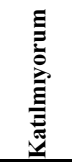 & 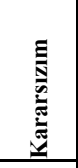 & 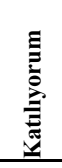 & 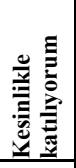 & $\frac{\sqrt[N]{0}}{\frac{2}{\pi}}$ \\
\hline $\begin{array}{l}\text { 2. Sermaye piyasalarında sağlıklı bir büyüme ancak finansal şeffaflık ile } \\
\text { sağlanabilir. }\end{array}$ & 0 & 4,3 & 2,9 & 58 & 34,8 & -- \\
\hline $\begin{array}{l}\text { 3. Finansal şeffaflık, finansal krizlerin ve skandalların önüne geçmede } \\
\text { etkilidir. }\end{array}$ & 0 & 2,9 & 2,9 & 60,9 & 31,9 & 1,4 \\
\hline $\begin{array}{l}\text { 4. Finansal tabloların raporlanmasında web tabanlı merkezi bir } \\
\text { raporlama dilinin kullanılması ile şirket yönetimlerinin finansal verilere } \\
\text { müdahale olanağının ortadan kaldırılmasl finansal şeffaflığl } \\
\text { sağlanmada etkili olacaktır. }\end{array}$ & 0 & 9,4 & 9,4 & 53,1 & 25 & 3,1 \\
\hline $\begin{array}{l}\text { 5. XBRL gibi Web tabanlı merkezi bir raporlama dili ile üretilmiş olan } \\
\text { finansal bilgiler yatırımcılara daha fazla güvence sağlayacaktır. }\end{array}$ & 0 & 3,1 & 21,9 & 56,3 & 18,8 & -- \\
\hline $\begin{array}{l}\text { 6. XBRL gibi Web tabanlı merkezi bir raporlama dili ile sürekli ve anlık } \\
\text { denetimin mümkün kılınması finansal şeffaflı̆̆ sağlamada etkili } \\
\text { olacaktır. }\end{array}$ & 0 & 3,1 & 15,6 & 50 & 31,3 & -- \\
\hline $\begin{array}{l}\text { 7. Web tabanlı merkezi bir raporlama dili ile periyodik finansal } \\
\text { raporların yerine anlık finansal raporlamaların yapılabilmesi finansal } \\
\text { seffaflı ortamın kuvvetlendirecektir. }\end{array}$ & 0 & 3,1 & 12,5 & 59,4 & 25 & -- \\
\hline $\begin{array}{l}\text { 8. XBRL'in ilerleyen yıllarda Türkiye'de potansiyel kullanımı mümkün } \\
\text { olacaktır. }\end{array}$ & 0 & 6,3 & 18,8 & 50 & 21,9 & 3,1 \\
\hline $\begin{array}{l}\text { 9. Türkiye'deki teknolojik altyapımız XBRL'i uygulamada yeterli } \\
\text { olacaktır. }\end{array}$ & 0 & 6,3 & 34,4 & 40,6 & 15,6 & 3,1 \\
\hline \multicolumn{7}{|c|}{ 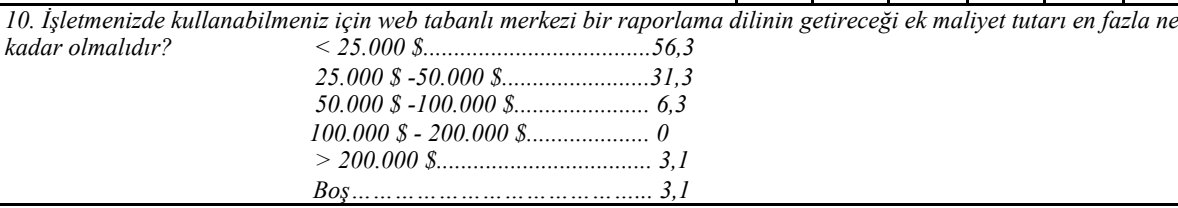 } \\
\hline
\end{tabular}

10. IMKB'ye bağlı firma yetkililerinin $\% 56,3$ 'ü web tabanlı merkezi bir raporlama dilinin uygulama maliyetlerinin 25.000 \$'in altında kalması gerektiğini belirtirken, \%31,3'lük dilim uygulama maliyetlerinin $25.000 \$-50.000$ \$arasinda olmas1 gerektiğini belirtmiştir. Verilen cevaplardan IMKB'ye bağlı firma yetkililerinin uygulanabilecek yeni bir altyapının maliyetlerinin çok yüksek düzeyde olmasını beklemedikleri görülmektedir. ABD’ndeki uygulamaya bakıldığında katlanılan maliyetlerin birbirlerinden farklı aralıklarda oldukları belirli bir tutar aralığı üzerinde yoğunlaşmadığı gözlenmektedir. Bu durum Türkiye’de katlanılabilir olarak görünen maliyet tutarından daha yüksek maliyete de katlanılabileceğini göstermektedir.

\section{Sonuçların Değerlendirilmesi}

- ABD'de ve Türkiye'de yapılan araştırma çalışmasinın değerlendirmelerinden XBRL uygulamasının finansal şeffaflığın sağlanmasında etkili olacağı konusunda ağırlıklı olarak hem fikir oldukları anlaşılmaktadır. Türkiye uygulamasında SPK yetkilileri XML, XBRL gibi altyapilar hakkında çok bilgi sahibi olmadıklarını bildirmişler ve bu durum kamunun bu konuda bilgilendirilme ihtiyacını ön plana çıkarmıştır. Mevcut bir web tabanlı merkezi raporlama altyapısının finansal raporlama sürecinde kullanılmasının finansal șeffaflık ortamının kuvvetlendirilmesinde önemli bir rol oynayabileceği Türkiyede yapılan uygulama sonuçlarında da görülmektedir. Aynı zamanda XBRL gibi ortak bir raporlama altyapisı ile periyodik finansal raporlamalar yerine sürekli finansal raporlar alınabilmesinin finansal şeffaflık ortamını kuvvetlendireceği yönde olumlu bir görüşte değerlendirmelerden anlaşılmaktadır.

XBRL'in ortak raporlama altyapisı ve ortak muhasebe standartlarına bağlı olarak aynı etiketleri kullanması nedeniyle finansal bilgi kullanıcılarına doğru, tutarlı ve güvenilir bir finansal veri alışveriş ortamı sağlamasının finansal şeffaflığın elde edilmesinde olumlu etki 
yaptığı düşünülmektedir. Değerlendirmeler katılımcıların ortak bir muhasebe standardının gerekliliği konusundaki görüşleriyle paralellik göstermektedir. $\mathrm{Bu}$ durum ise katılımcilara XBRL'in beklenen finansal şeffaflık ortamını sağlayabileceği düşüncesine sahip olmalarına neden olmakta ve XBRL'in en önemli hayata geçirilme nedenlerinden birisinde çok önemli adımlar atıldığını göstermektedir.

- XBRL kullanıcıları XBRL ile üretilmiş olan finansal tabloların yatırımcilara yatırım kararlarında genel olarak daha fazla güvence sağladığına inanmaktadırlar. Aynı değerlendirme Türkiye uygulamasında IMKB'ye bağlı firma yetkililerinde de görülmektedir. Bu durum XBRL’in gerek finansal şeffaflık için gerekse finansal şeffaflı̆̆ın sağlanabilmesi amacıyla gereken uygulamalar yolunda ne kadar önemli bir araç olduğunun diğer bir göstergesidir. XBRL ile hazırlanan finansal tablolara olan güvenin daha fazla olması yatırımcıların yatırım kararlarında kendilerini daha rahat ve güvende hissetmelerine neden olacaktır ki bu sermaye piyasalarında beklenen büyümenin XBRL’in sağlayacağı güven ortamı ile mümkün olacağını ortaya koymaktadır. Bununla beraber bu yargiya katılmayanların oranının dikkate alınması gereken büyüklükte olmasının XBRL'in uygulama seviyelerinde halen arzu edilen düzeyde olmamasından kaynaklanan görüş farklılıklarının doğmasına neden olduğu düşünülmektedir.

- Değerlendirmeler XBRL kullanıcılarının XBRL’in finansal şeffaflığı sağlamasına rağmen halen finansal manipülasyonun mümkün olacağına inandıklarını göstermektedir. Katılımcılar, XBRL’in finansal şeffaflığı sağlayacağına inanmasına rağmen finansal güvenilirliği sağlayamayacağına inandıkları görülmektedir. Temel olarak bu düşünce, şirket yönetimlerinin halen tüm seviyeleri ile uygulama firsatı bulamayan XBRL projesinde bugünkü uygulama aşamaları itibarı ile XBRL formatına dönüştürüp yayınladıkları finansal bilgiler üzerinde manipülasyon yapabileceklerini açıkça ortaya koymaktadır. ABD Menkul Kiymetler Komisyonu XBRL raporlamasını en kısa sürede hayata geçirmek için çabalamış ve bu aşamada uygulama düzeyi ile herhangi bir yaptırım zorunluluğu getirmemiştir. Uygulamanın ileriki aşamalarında şirket yönetimlerinin manipülasyon yapabilme olanağ 1 proje adım adım ilerlerken giderek azalabilecektir. Bu durum ise şirket yönetimlerinin yayınlanan finansal tablolar üzerindeki etkilerini azaltacak ve finansal şeffaflık ortamının güçlenmesine yardımci olacaktır.

- XBRL kullanıcıları finansal veri raporlamasında farklı muhasebe standartlarına rağmen XBRL’in finansal şeffaflığı sağlayacağını düşünmektedirler. Amerika Birleşik Devletlerinde büyük ölçekli birçok firmanın muhasebe kayıtları U.S. GAAP’e göre tutulmaktadır. ABD Menkul Kiymetler Komisyonu XBRL'in kullanımını sermaye piyasalarında yer alan tüm şirketler için kademeli olarak zorunlu hale getirmiştir. XBRL'in ilk etiketleri çok uluslu şirketlerde daha yaygın olarak kullanılan muhasebe standartları setinin IFRS olmasından dolayı komisyonun öncülüğünde IFRS'e göre hazırlanmıştır. XBRL'in kullanımı firmalara muhasebe kayitlarını IFRS'e göre düzenleme zorunluluğu getirmektedir fakat büyük ölçekli firmaların ısrarcı tavırları ve kuvvetli lobileri sonucu komisyon U.S. GAAP bazında da bir etiketleme seti hazırlamak zorunda kalmıştır. Farklı muhasebe standartlarına rağmen XBRL'in finansal şeffaflık konusunda kullanıcılara güvence vermesi XBRL'in altyapisinin ne kadar kuvvetli olduğunun ve bağlı bulunduğu etiketler doğrultusunda yatırımcilara kanuni düzenlemeler ve uygulamalar çerçevesinde hizmet ettiğinin bir göstergesidir. Katılımcıların XBRL'in finansal güvenilirliği sağlayamayacağını düşünmelerine rağmen farklı muhasebe standartlarında etkili olacağını düşünmeleri de bunun farklı bir göstergesidir.

- Firmaların XBRL raporlamasında etiketlemedeki eksiklikler ve yetersizlikler sebebiyle ek veri etiketleme yapma yetkisine sahip olmasinın finansal şeffaflığı zedeleyecek olması görüşü katılımcilar tarafından doğrulanmakla beraber yine yüksek oranda bir katılımcı kitlesi bu görüşe katılmamıştır. Ek veri etiketleme yetkisinin şirketlerden alınmasının finansal şeffaflı̆̆ın korunması sebebiyle önemli olduğu katılımcıların değerlendirmelerinden anlaşılmakla beraber XBRL kullanıcılarının bir kısmının da bu yetkinin şirket yönetimlerinde kalmasının gerekliliği üzerinde görüş bildirmiş olması şirket yönetimlerinin finansal tablolar üzerinde yapmayı istemiş olduğu makyajlama hakkını ellerinde tutma 
isteği olarak anlaşılmaktadır. Bu yargıya olumlu cevap veren katılımcıların değerlendirmeleri üzerinde yapılan istatistikî analizler göstermektedir ki ek veri etiketleme yapabilme yetkisinin şirket yönetimlerinde olmaması gerektiğini düşünen katılımcilar finansal manipülasyonların yapılabilme olanağının varlığı yönünde görüş bildirmişlerdir.

Türkiye uygulamasında da IMKB'ye bağlı şirket yetkililerinin değerlendirmelerinden şirket yönetimlerinin finansal verilere müdahale olanağının ortadan kaldırılmasının finansal şeffaflı̆̆ sağlamada etkili olacağını düşündükleri anlaşılmaktadır. XBRL uygulamasının hayata geçirilmesinin en önemli nedenlerinden birisi şirket yönetimlerinin finansal tablolar üzerinde finansal manipülasyon yapabilme ihtimalinin azaltılması olduğundan, ek veri etiketleme yetkisine sahip olmak şirket yönetimlerinin tamamen bu hedefin dışına çıkabilmesi anlamına gelmektedir.

- XBRL ile halka açıllanan finansal tabloların daha tutarlı olduğu görüşü XBRL kullanıcılarının büyük çoğunluğu tarafından doğrulanmaktadır. Temelde tutarlılık aynı ilkeler ile farklı dönemlerde benzer raporlamalar yapmayı temsil etmektedir. XBRL'in raporlama altyapısı itibariyle kullandığı etiketleme altyapısı ve bağlı bulunduğu IFRS veya U.S. GAAP muhasebe standartları seti XBRL formatındaki raporların firmaların güncel verileri üzerinde farklı dönemler itibariyle tutarlı raporlar yapabilmesine olanak tanımaktadır. Bu durumun finansal bilgi kullanıcılarının aldıkları raporlar doğrultusunda tespiti kullanıcıların değerlendirmelerinden de açıkça anlaşılmaktadır. Finansal verilerdeki tutarlılığın sağlanmasında en önemli etmenlerden biri kullanılan muhasebe standartları doğrultusunda belirlenen kurallar ile oluşturulmuş etiketlere bağlı kalarak finansal raporlama yapılabilmesidir. Katılımcılar şu an ki uygulama aşamaları ile finansal manipülasyon olanağının halen mevcut olduğunu belirtmesine rağmen finansal raporlamalarda XBRL'in daha tutarlı verilerin yayınlanmasında etkili olduğunu düşündükleri görülmektedir.

- Finansal bilgilerin dönemsel olarak finansal bilgi kullanıcılarına ulaştırılmasında XBRL'in hızlandırıcı etkisi olduğu değerlendirme sonuçlarından çok net bir şekilde anlaşılmaktadır. Sermaye piyasalarında yer alan firmaların birçoğu çok uluslu firmalardır ve genel itibariyle farklı ülkelerde yer alan tüm birimlerinin dönemsel finansal kapanış işlemlerinin tamamlanmasının ardından konsolide finansal tablolarını oluşturabilmek amaciyla yoğun bir konsolidasyon sürecine girmektedirler. Tüm bu işlemlerin en alt birimlerden başlayarak holding genelinde konsolidasyon sonrası aşamaya kadar sonlandırılması süreci ciddi boyutlarda zaman almaktadırlar. XBRL'in tüm kademelerde uygulama süreci bulması ve tüm konsolidasyon sürecinin azalmasında ve finansal bilgi kullanıcılarına finansal tabloların iletilmesinde çok önemli bir rol oynaması değerlendirme sonuçlarında da net bir şekilde incelenmektedir. Bu durum ise yayınlanan finansal tabloların daha kısa sürelerde finansal bilgi kullanıcılarına iletilebileceği altyapının sağlanması anlamına gelmektedir ve XBRL'in finansal şeffaflığ sağlayan unsurlardan zamanlılık kavramındaki etkinliğini göstermektedir.

- ABD'de yapilan uygulama sonucu sürekli ve anlık denetim imkânının XBRL ile sağlanabilirliği yapılan değerlendirmelerden gözlenmektedir. XBRL finansal bilgilere anlık erişim imkânı tanıyan bir altyapı bütünü olması itibarı ile getirmiş olduğu bu esnek ve gelişmiş özellikleriyle aslında yıllardır üzerinde ciddi arayışlar ve çalışmalar yapılan sürekli denetim imkânına da bir çözüm gerektirmektedir. Finansal verilere ve muhasebe kayıtlarına anlık erişim olanakları tanıyan XBRL ile gerek bağımsız denetim kuruluşları gerekse devlet otoriteleri mevcut kayitları ve finansal verileri anlık ve sürekli bir şekilde denetleme olanağ 1 bulabileceklerdir. Devlet otoritelerinin kaynak ve zaman kısıt'ı dolayısı ile denetim olanaklarını çok fazla genişletememesi bağımsız denetim kuruluşlarının sermaye piyasalarında yer alan büyük firmaların denetimlerinde önemli rol sahibi olmalarına sebep olmuştur. Bağımsız denetim kuruluşları kısa dönemler içerisinde dahi milyonlara varan muhasebe kayıtları yapan bu çok büyük ölçekli firmalarda kısıtlı vakitler içerisinde ancak örneklem yoluyla denetim gerçekleştirebilmektedirler.

Denetim süreçleri sonunda vermiş oldukları raporlarda sadece yapılan örneklem sonucu bir denetim raporu sunabilmektedirler. Bu durum tam bir güvence sağlamamakla beraber örneklem incelemeleri dışında kalan muhasebe hilelerinin de mevcut ola- 
bileceği riskini artırmaktadır. Bu sebeplerle sürekli denetim olanağının hayata geçirilmesi büyük önem arz etmektedir. XBRL ile ilgili bağımsız denetim kuruluşları ve devlet otoriteleri firmaların veritabanlarında anlık inceleme gerçekleştirebileceklerdir. Denetim yapabilmek amacıyla denetçilerin firmalarda bulunma zorunluluğunun olmaması ve sürekli denetim imkânının gelişmesi XBRL'in hayata geçirdiği en önemli ve en değerli yeniliklerden birisidir.

Türkiye uygulamasında IMKB’ye bağlı firma yetkililerinin sürekli ve anlık denetim imkânının mümkün kılınmasının finansal şeffaflığın sağlanmasında fayda sağlayacağını düşündükleri açıç̧a görülmektedir. $\mathrm{Bu}$ durum ise Türkiye'de muhtemel bir XBRL uygulamasının finansal şeffaflık ortamını kuvvetlendirmede önemli boyutta etkili olabileceğinin bir diğer göstergesidir.

- Bilgi teknolojileri alanında yaşanan baş döndürücü gelişmelerden ABD Menkul Kıymetler Komisyonunun esinlenmesi ile ortaya çıkmış olan XBRL'in bilgisayar teknolojilerine aşırı güven doğrultusunda oluşturulmuş olmasından dolayı yeni bir finansal krize yol açabileceği konusundaki düşünceleri katılımcıların ağırlıklı olarak kabul etmediği görülmektedir. Bununla beraber katılımcıların önemli bir orandaki kıs$\mathrm{m} 1$ ise bu ihtimali göz ardı etmemiştir ve mevcut finansal verilerin kötü niyetli bir kullanımla veya güvenlik açığıyla değiştirilme ihtimalinin gerek yatırımcıları gerekse diğer finansal bilgi kullanıcılarını yanlış yönlendirebileceğini ve sonucunda da yeni bir finansal krize yol açabileceğini belirtmişlerdir. Yargıya olumlu yönde yanıt verenlerin değerlendirmelerinden firmaların finansal verilerinin saklı olduğu veritabanlarının anlık erişime açık olmasından dolayı muhtemel güvenlik sıkıntıları yaşama riskinin mevcut olduğunu düşündükleri bu değerlendirmelerden anlaşılmaktadır.

- XBRL kullanıcılarının, XBRL raporlamasının işletmelerinde uygulanabilmesi için uzmanlık gerektirdiği konusundaki düşünceleri ağırlıklı olarak olumlu yöndedir. XBRL'in gerek etiketleme altyapısı gerekse ABD Menkul Kıymetler Komisyonunun belirlemiş olduğu raporlama şartlarında uygulanması belirli bir çalışma, bilgi ve tecrübe altyapısı gerektirmekle beraber komisyonun uygulama seviyeleri ile ilgili olarak bir zorunluluk bildirmemesi firmaları bu konuda özgür bırakmıştır. Uygulamadaki bu farklılıkların uzmanlık ihtiyacı konusunda verilmiş cevapların dağılımında da görülmektedir. İşletmelerin birçoğunda danışman firmalar raporlama süreci boyunca hizmet vermektedirler. Bununla beraber XBRL raporlamasını veritabanlarının altyapısı içerisinde uygulamayı tercih etmeyip halen konsolide finansal tablolarını yüzeysel olarak XBRL formatına çevirip raporlama yapan firmaların cevaplarından ciddi oranda uzmanlık gerektirmediği düşüncesi olduğu anlaşılmaktadır.

- Yapılan değerlendirmelerden XBRL kullanıc1larının uygulama maliyetlerinin küçümsenecek boyutlarda olmadığı XBRL'in, getirilerinin ve faydalarının, bu maliyetlere katlanmaya değer olduğunu düşünmekte oldukları görülmektedir. $\mathrm{Bu}$ durum katılımcılar açısından finansal verilerin kaydedilmesi ve raporlanması sürecinde XBRL kullanımının artı bir değer oluşturduğunu göstermektedir. Katılımcıların farklı finansal raporları hazırlama süreçlerini ve manuel iş yükünü azaltabilecek, kontrol ve analiz süreçlerini arttırabilecek bu yeni altyapı hakkında olumlu görüş bildirmeleri katlanılan maliyetlere değdiğinin bir diğer göstermektedir. Sermaye piyasalarında işlem gören firmaların bilgi teknolojileri alanında yaptıkları harcamaların yanında uygulama seviyelerine göre farklılık gösteren XBRL raporlama maliyetlerinin çok büyük olmadığı görülmektedir. Bununla beraber yatırımcıların güvenlerini tekrar kazanmasında etkili olan XBRL'in firmalar tarafından tercih edilmesinin ve uygulama maliyetlerine katlanılmasinın en büyük faydasının XBRL’in vereceği güven ortamı ile uzun vadede firmaların elde edecekleri ekonomik büyüme olacaktır.

- Değerlendirmeler sonucunda XBRL'in bugünkü beklentileri karşıladığı yönde bir görüş hâkim olmakla beraber bu görüşe karşıt olanların değerlendirmelerinden bugünkü beklentilerin bazı bilgi kullanıcıları açısından yeterli olmadığı anlaşılmaktadır. $\mathrm{Bu}$ yönde görüş bildirmiş olan katılımcıların cevaplarından finansal manipülasyonun elimine edilip finansal şeffaflık ortamını kuvvetlendirme ihtiyacı içinde olmasının henüz uygulamadaki eksiklikler dolayısı ile sağlanamamış olmasını düşündükleri tahmin edilmektedir. Yapılan değerlendirmeler ise yine finansal mani- 
pülasyon ihtimali yargısına verilen cevaplar ile uyum içerisindedir ve XBRL altyapısını dönemsel olarak daha ileri seviyeye taşımayı hedefleyen ABD Menkul Kiymetler Komisyonunun hedefleri ile paralellik göstermektedir.

- Henüz uygulama aşamasını tamamlamamış fakat her yil üzerinde ciddi boyutlarda gelișim kazanılan XBRL uygulamasındaki gecikmelerin büyük firmaların baskısı sonucu U.S. GAAP bazında ikinci bir etiketleme hazırlamak durumunda kalan komisyonun yaşadığı bazı gecikmelerin önemli bir etken olduğu düşünülmektedir.

- XBRL kullanıcılarının birçoğu ABD Menkul Kıymetler Komisyonu tarafından kullanımı yasal bir zorunluluk olarak belirlenen XBRL'in yasal zorunluluğu olmasa bile kullanılacağının tercih edileceği yönünde düşündüklerini belirtmişlerdir. XBRL'in sadece ilgili devlet otoriteleri, kamu kurum ve kuruluşları veya diğer finansal bilgi kullanıcıları için değil aynı zamanda firmaların iç raporlamasında da çok önemli bir yere sahip olduğu ve getirmiș olduğu esneklik ile firmalar için önemli bir araç olduğu verilen cevaplardan da anlaşılmaktadır. Aynı zamanda XBRL raporlaması ile yatırımciların yatırım kararlarında kendilerini daha güvenilir ve şeffaf bir ortamda hissetmesinin firmaların birçoğunun arzu ettiği bir durum olduğu düşünülmektedir çünkü bu durum beraberinde firmaların ekonomik anlamda gelişmesini destekleyebilecektir. Bununla beraber bu görüșe sahip olmayan katılımcıların cevaplarından bazı firmaların şeffaflık ortamını tercih etmek istemedikleri tahmin edilebilir.

- XBRL kullanıcılarının büyük çoğunluğu XBRL'in uygulama maliyetleri hakkındaki değerlendirmelerinde uygulama maliyetlerini 100.000 \$'in altında olduğunu belirtmişlerdir. XBRL'in uygulama seviyesinin uygulamaya geçiş aşamasında ABD Menkul Kıymetler Komisyonu tarafından yasal bir zorunluluk olarak getirilmemesi firmaları daha çok sadece yapmak zorunda oldukları yasal raporlamaları yerine getirecek şekilde uygulamayı başlatmaya yöneltmiștir. Firmaların birbirlerine yakın büyüklükte ve yapıda olduğu düşünülürse, XBRL’in geleceği hakkında farklı düşüncelere sahip oldukları yapılan değerlendirmelerden anlaşılmaktadır. Bu durum ise uygulama boyutlarındaki tercihlerini etkilemektedir. Uzun vadede XBRL'in geleceği olduğunu düşünen firmalar kendi tercihleri doğrultusunda detaylı bir uygulama süreci geçirmişler, bu durumdan emin olmayan firmalar ise kısa dönemli ve çok detaylı olmayan çözümler ile yüzeysel raporlama yoluna gitmişlerdir.

Firmaların bu konudaki tercihleri firmaların maliyetleri konusundaki değerlendirmelerinden de anlaşılmaktadır. Firmaların uygulama seviyeleri tercihleri uygulama maliyetlerinin farklı boyutlarda seyretmesine neden olmaktadır. Uygulama maliyetlerinin 200.000 \$'ın üzerinde gerçekleşmesi bile ABD'de SEC’e bağlı olarak çalışan halka açık şirketlerin ortalama hâsılalarına oranla 1:10.000 oranının altında kalmaktadır. Dolayısı ile bu ölçekte çalışan firmalar için XBRL'in uygulama maliyetlerinin ciddi bir problem oluşturmayacağı ve hatta uzun vadede destekleyeceği ekonomik büyüme ile uygulama maliyetlerinin XBRL'i hayata geçirmeye değer olacağı düşünülmektedir.

Benzer değerlendirme Türkiye uygulamasında da görülmektedir. Türkiye de IMKB’ye bağlı olarak çalışan halka açık şirket yetkililerinin değerlendirmelerinden XBRL'in altyapı olarak Türkiye'de uygulanabileceğini ve ileriki yıllarda muhtemel uygulama alanı bulabileceğini düşündükleri anlaşılmaktadır. IMKB'ye bağlı firma yetkililerinin muhtemel bir XBRL uygulamasinın maliyetlerinin ağırlıklı olarak 100.000\$’in altında gerçekleşmesini bekledikleri değerlendirmelerden görülmektedir. Bu beklenti bilgi teknolojileri kapsamında katlandıkları tüm uygulama maliyetlerine kıyasla XBRL uygulaması için düşündükleri yatırım büyüklüğünü göstermektedir.

- XBRL kullanıcılarının XBRL'in firmalarda uygulanması için çalışan uzman sayısı konusundaki değerlendirmeleri XBRL'in uygulanma maliyetleri konusundaki cevaplarıyla paralellik göstermektedir. Değerlendirmelerin büyük çoğunluğu firmalarda çalışan uzman sayısının 6 kişinin altında kaldığını göstermektedir. Bu da bu büyüklükte firmalar açısından düşünüldüğünde fazla bir personele gerek olmadığını düşündürmektedir. Bununla beraber XBRL'in uzun vadede firmalarda yer alacağını düşünen katılımcıların detaylı proje uygulamaları sonucu farklı alanlarda çalışan uzman sayısına ihtiyaçları artmaktadır. Uzmanlık gerektiren alanlar sadece konsolide finansal tabloların XBRL formatına çevrilmesi ile sinırlı kalmayıp, aynı zamanda raporlama modüllerinin XBRL formatında raporlama yapabilmesi için gereken altyapının kurulması, bu altyapının kurulması aşamasında etiketlerin veritabanındaki finansal veriler ile eşleştirilmesi 
ve hatta veritabanının en alt seviyesinde finansal verilerin kayıt yapısının XBRL platformuna uygun olarak düzenlenmesine kadar değişiklik göstermektedir. Bu artan ihtiyaç beraberinde uzman sayısını 6-12 kişi arası, 12-24 kişi arası ve 24 kişinin üzerinde olacak şekilde şekillendirmektedir.

\section{Sonuç}

Türkiyede yapılabilecek olan muhtemel XBRL altyapısının uygulanmasında ABD'de yapılan uygulama çalışmalarında yaşanan sıkıntılar ve zorluklar göz önüne alınarak XBRL’e geçiş süreci daha verimli bir hale getirilebilecektir. ABD'deki uygulamada en büyük sıkıntıların mevcut etiketlemenin eksikliklerinden kaynaklanıyor olması Türkiyede muhtemel bir uygulamanın hayata geçirileceği proje takviminden önce kurulacak etiket oluşturma kurulları tarafından ilgili otoriteler ile çalışılarak önlenebilecek ve uygulamanın kısa sürede başarıly hayata geçirilebilmesinde önem teşkil edecektir. Aynı zamanda uluslar arası finansal raporlama standartlarının Türkiyede de kabul edilmiş olması ve uyumlaştırma sürecinin tamamlanması UFRS'ler bazında etiketlerini oluşturmuş olan ABD Menkul Kıymetler Komisyonunun uygulamalarından daha aktif bir şekilde yararlanabilmemizi sağlayacaktır. $\mathrm{Bu}$ olumlu yanlar doğrultusunda Türkiye’de XBRL’e geçiş sürecinin verimli bir şekilde tamamlanması mümkün olabilecektir.

Mevcut altyapının Türkiye'de uygulanmasının Borsanın yainda maliye bakanlığı gibi devlet otoriteleri tarafından da kullanılması şirket denetimlerinde yeterli hesap uzmanları ve müfettiş kadrosuna sahip olmayan ve gerçekleştirdiği denetim süreçlerinin sıklığını artırıp kayıtsız ekonominin önüne geçmek isteyen gelir idareleri için önemli fursatlar sunacaktır. Uygulamaya henüz alınmış olan "Sesam" adlı yeni bir yazılımın maliye bakanlığı bünyesinde kullanılmaya başlanarak mükelleflerin defterlerini elektronik formatta vermesi sağlanarak bu program vasitasılyla Excel formatına dönüştürülmesi ve hesap uzmanlarına denetim kolaylı̆̆ sağlanmaya çalışılması maliye bakanlığı bünyesinde denetim amacıyla yapılmaya çalışılan iyileştirmelere iyi bir örnek teşkil ederken XBRL’in sağlayacağı sınırsız faydaların önemini de bir kez daha ön plana çıarmaktadır. XBRL uygulaması ile kurumlar arası iletişim altyapısı artacak ve kayıtsız sermayenin önlenmesinde olumlu adımlar atılabilecektir. Tüm bu süreç ise beraberinde daha güçlü bir ekonominin ve büyümenin elde edilmesini sağlayabilecektir.

\section{Kaynakça}

6102 sayll Türk Ticaret Kanunu, http://www.mevzuat. gov.tr Erişim Tarihi 11.07.2013

Anderson, A. (2002). The Business Reporting Model of the Future and Real Time Information Flows. AICPA. September 3. pp. 88-102.

Berkeley, A. (2008). The Road To Beter Business Information: Making A Case For XBRL. A Conversation with Nasdaq. Microsoft and Pricewaterhouse Coopers, 2008 pp. 3-11.

Best, K. (2009). XML ve Finans. http://www.softwareag.com/turkiye/FAQ/xmlvefin-ans.htm. Erişim Tarihi: 11.12.2009.

Garbellotto, G., Hannon, N. (2005). Why XBRL Is A 'Business' Reporting Language Strategic Finance. May 2005. pp. 4-6.

Kamu Gözetimi Muhasebe ve Denetim Standartları Kurumu, XBRL Türkiye Temsilciliğinin Kurulması ile ilgili basın açıklaması http://www.kgk.gov.tr Erişim tarihi 06.12.2013

Malhotra, R., Garritt, F. (2004) Extensible Business Reporting Language: The Future Of E-CommerceDriven Accounting. International Journal of Business, ISSN:1083-4346. 9/1. 2004. pp. 59-66.

Murthya, Uday. S., Groomerb, S. M. (2004). A Continuous Auditing Web Services Model For XML-Based Accounting Systems. International Journal of Accounting Information Systems, 5. pp. 139-163.

Ohata, M. (2008). Change Report: What's Your XBRL Readiness? Business Performance Management. December 2008. pp. 3.

Teixeira, A. (2005). What XBRL Means For IFRS. Chartered Accountants Journal. June 2005. pp. 11-27.

Waldt, D., (2004). XBRL: The Language Of Finance And Accounting. http://www.xml.com/ pub/A/2004/03/10/xbrl.html. Erişim Tarihi: 10.03.2010.

XBRL (2009). Taxonomy http://www.xbrl.org/taxonomy/int/br/common/gcd/2002-10-15. Erişim Tarihi: 11.09.2009.

XBRL (2009). IAS and Reporting. http://www.xbrl. org/taxonomy/int/fr/ias-/ci/edap/2002-11-15. Erişim Tarihi: 11.09.2009. 